\title{
LA GARANTÍA DEL CONTENIDO ESENCIAL DE LOS DERECHOS FUNDAMENTALES
}

\author{
PETER HÄBERLE
}

\author{
MARCELA ROSA ABRAHÃO ${ }^{1}$
}

\begin{abstract}
RESUMO: A presente resenha expõe as ideias principais da teoria de direitos fundamentais de Peter Häberle. O autor constrói a ideia de convivência e concordância das dimensões de liberdade e institucional dos direitos fundamentais. A figura do legislador como possibilitador do exercício das liberdades em conformidade com a realidade social rompe com a ideia tradicional de legislação versus direitos fundamentais. A explicitação da garantia do núcleo essencial dos direitos no ordenamento constitucional torna-se, então, dispensável frente às ideias de completude do sistema e da realidade, da consequente mudança de perspectiva da atuação do legislador, que não tem como intenção primeira a restrição dos direitos fundamentais e, finalmente, da possibilidade de interpretá-la em princípios constitucionais.
\end{abstract}

PLAVRAS-CHAVE: Direitos Fundamentais; Teoria Institucional dos Direitos Fundamentais; Teoria Interna dos Limites aos Direitos Fundamentais.

ABSTRACT: This review presents the main ideas of the theory of fundamental rights from Peter Häberle. The author constructs the idea of coexistence and concordance of institutional and freedom's dimensions from fundamental rights. The figure of the legislator as enabler of the exercise of freedoms in accordance with the social reality breaks with the traditional idea of law versus rights. The explicit guarantee of the essential core of the fundamental rights in the constitutional order becomes unnecessary due to the ideas of completeness of the system and the reality, of the change in the perspective of the legislature's role, that is not primarily intended to restrict the fundamental rights and, finally, of the possibility to interpret it on constitutional principles.

KEYWORDS: Fundamental Rights; Institutional Theory of Fundamental Rights; Internal Theory of Fundamental Rights Limits.

SUMÁRIO: Introdução; 1 Apresentação do Livro: As Questões Centrais da Obra; 2 Crítica às ideias do Autor; 2.1 Breve Introdução ao Pensamento do Autor; 2.2 Concepção do Catálogo de Direitos como Normas Princípios ou Normas Regras e a Adequação do Pensamento a uma Teoria de Limitação dos Direitos Fundamentais; 2.3 O Núcleo Essencial; Referências Bibliográficas.

Resenha recebida em 02.12.2011. Resenha aceita para publicação em 12.03.2012.

${ }^{1}$ Especialista em Direito Público pela Pontifícia Universidade Católica do Rio Grande do Sul (PUCRS), Especialista em Direitos Humanos pela Faculdade de Direito da Universidade de Coimbra (FDUC), Mestranda em Direitos Fundamentais na Faculdade de Direito da Universidade de Lisboa (FDUL). marcelaabrahao@yahoo.com.br 
SUMMARY: Introduction; 1 Presentation of the Book: The Central issues of the Work; 2 Comments to the Author's Ideas; 2.1 Brief Introduction to the Author's thought; 2.2 Conception of the Catalog of Rights as Standards of Rules or Standards of Principles and the Adequacy of the ideas to an Appropriate Theory of Limitation of Fundamental Rights; 2.3 The Essential Core; Bibliographical References.

\section{INTRODUÇÃO}

A presente resenha analisa a obra "La Garantia del Contenido Esencial de los Derechos Fundamentales" de autoria do jurista alemão Peter Häberle. ${ }^{2}$ O objetivo do trabalho é apresentar de forma sintética e crítica os pontos de maior importância.

Peter Häberle é motivado, frente à inexistência de consenso sobre questões básicas conceituais e dogmáticas, a desenvolver uma interpretação sistemática da garantia do núcleo essencial dos direitos fundamentais, com base em questões metodológicas e materiais, e a combinar, para tal, concepções do passado com novas ideias. Reflete sobre um pensamento "especificamente jurídico-constitucional", ${ }^{3}$ salientando o conceito de direito e sua relação com a liberdade. Divide o livro, portanto, em quatro capítulos os quais serão apresentados a seguir.

\section{APRESENTAÇÃO DO LIVRO: AS QUESTÕES CENTRAIS DA OBRA}

Peter Häberle parte da necessidade de determinar o sentido dos direitos fundamentais, a inserção desses direitos no conjunto (determinação de sua função) e o esclarecimento de sua relação com outros bens jurídicoconstitucionais para, enfim, poder responder a questão latente: a problemática da definição do núcleo essencial.

A começar pelo sentido dos direitos fundamentais no ordenamento constitucional e sua significação constitutiva para a totalidade do sistema jurídico de valores, o autor define os direitos fundamentais como direitos que são expressões do status libertatis - atualizável ao longo do tempo - com a qualidade de "valores supremos". Caracteriza a "generalidade material" da Constituição - a que fazem parte estes conteúdos fundamentais - como parâmetro axiológico do direito, pois ela seria a expressão dos valores das pessoas que formam determinada comunidade que os fixam, determinando, a partir disso, o nível e posição dos bens jurídicos.

\footnotetext{
${ }^{2}$ HÄBERLE, Peter. La Garantia del Contenido Esencial de los Derechos Fundamentales em la Ley Fundamental de Bonn: uma contribuición a la concepción institucional de los derechos fundamentales y a la teoria de la reserva de la ley. Trad. Joaquín Brage Camazano. Madrid: Dykinson, 2003. Obra traduzida do original: HÄBERLE, Peter. Die Wesensgehaltgarantie des Art. 19 Abs. 2 Grundgesetz: Zugleich ein Beitrag zum institutionellen Verständnis der Grundrechte und zur Lehre vom Gesetzesvorbehalt. Karlsruhe: Müller, 1962. A referência a esta última versão dar-se-á no corpo do trabalho através da expressão: "versão alemã".

${ }^{3}$ Idem, p. 3; versão alemã: p. 3.

${ }^{4}$ Idem, p. 7; versão alemã: pp. 4-5.

${ }^{5}$ Idem, p. 9; versão alemã: p. 6.
} 
Refere que os direitos fundamentais devem ser interpretados em conjunto, como forma de expressão da unidade da Constituição e como evidência de que estariam vinculados à determinada comunidade. Os direitos não são meramente a expressão da liberdade do indivíduo - em sua dimensão negativa, com natureza individualista -, mas cumprem sua função social, a qual vincula o legislador e os cidadãos. ${ }^{6}$ Tal forma de interpretação impõe como limite à atividade legislativa a observação do conjunto dos bens sistematizados na Constituição, não sendo concebida a possibilidade de interpretação de valores impostos "desde fora", mas de imanência dos mesmos. ${ }^{7}$ A interpretação deve ser do bem jurídico em si e sua atuação no conjunto, pensamento que repugna qualquer tentativa de escalonamento de valores em virtude de uma hierarquia qualquer. ${ }^{8}$

A partir disso, expõe que os direitos fundamentais são necessários e condicionados pela comunidade, ${ }^{9}$ e vice-versa, sendo também imprescindíveis para a existência dessa. Defende que quando se priva um cidadão de seus direitos, estar-se-ia prejudicando toda a sociedade e tal reciprocidade de condicionamento existe também entre os diferentes direitos fundamentais de um mesmo titular, quando o sentido e realização de um direito dependem da existência de outro. ${ }^{10}$

O exercício dos direitos fundamentais como direitos de liberdade e de personalidade inseridos e em diálogo com a ordem social contrapõe-se à ideia de direitos fundamentais contra a ação do Estado e desse como dominante frente a seus súditos, relação essa que exige a interpretação no sentido do "entrecruzamento de interesses públicos e individuais" ${ }^{11}$ e

\footnotetext{
${ }^{6}$ A função social e o interesse individual estão em igualdade hierárquica (HÄBERLE, Peter. La Garantia del Contenido Esencial de los Derechos Fundamentales em la Ley Fundamental de Bonn. p. 13; versão alemã: p. 10), restando excluída, dessa forma, qualquer concepção unilateral de uma ou outra dimensão.

${ }^{7} \mathrm{O}$ autor explica a ideia de correlação dos valores: "Os concretos valores jurídicos da Lei Fundamental não se contrapõem como estranhos e incomunicáveis uns aos outros. Se remetem uns aos outros e estão em uma relação imanente (...) Quando têm lugar valorações de bens jurídicos, isso sucede de modo que se reafirma tanto o bem singular como o conjunto, e se alcança um equilíbrio entre os bens jurídicos concorrentes" (Idem, p. 9; versão alemã: pp. 6-7).

${ }^{8}$ Salientando de forma enfática: "Se se impõe um âmbito de valores desde cima, se desconheceria também o valor intrínseco e a autonomia do jurídico" (Idem, p. 10; versão alemã: p. 7). Concebe uma ordem de valores que deve ser constantemente atualizada.

${ }_{9}^{9}$ Desta dependência decorre a exigência de condições sociais razoáveis e igualitárias para o exercício das liberdades fundamentais. O Estado que não estabelece uma realidade equilibrada, não dispõe do "resultado coletivo pretendido pela Constituição" (Idem, p. 18; versão alemã: p. 16)

Assim, por exemplo, no caso da liberdade de consciência em que se vê fundamentada a liberdade religiosa, o que faz com que "se protejam e se fortaleçam reciprocamente" (Idem, p. 16; versão alemã: pp. 13-14). Igualmente condicionadas estão as normas de direito penal e os direitos fundamentais, embora não se encontrem todas nesta relação de reciprocidade, já que as primeiras exercem um papel de proteção em relação aos segundos (Idem, pp.17-18; versão alemã: pp. 14-15).

${ }^{11}$ Isso se daria pelo fato de que quando se afeta uma liberdade constitucionalmente protegida, estar-se-á afetando também a coletividade. Peter Häberle exemplifica tal assertiva com os
} 
não limitadora do poder dominante estatal. ${ }^{12}$ Toda a intervenção nos direitos fundamentais tem função de conformação desses mesmos direitos. A limitação, acompanhando tal raciocínio, serve também ao titular do direito limitado, já que pretende o exercício "correto" do direito em benefício da comunidade e, por isso, da manifestação individual da personalidade em consonância com o todo social. ${ }^{13}$

Caracteriza, então, os limites do núcleo essencial dos direitos fundamentais a partir do princípio da ponderação de bens, salientando que os limites permitem a relação de convivência dos direitos fundamentais com o restante de bens que integram a Constituição. Considera a ponderação de bens a técnica empregada para a definição e limitação dos direitos quando a restrição é proveniente de regras gerais. ${ }^{14}$ A situação de conflito entre direitos ou entre esses e bens gera outro direito fundamental, fruto da sua coexistência no âmbito constitucional. ${ }^{15} \mathrm{Em}$ que pese a existência do dever

casos da tutela do direito à vida, à propriedade, à liberdade, que são, no Estado Social de Direito, "uma exigência legítima tanto do indivíduo como da comunidade, isto é, existe nos interesses públicos e privados" (Idem, p. 23; versão alemã: p. 21). Daí decorre a ideia de que a limitação a um direito fundamental não se origina exclusivamente de um interesse público, pois se a norma fundamental não é a expressão do interesse apenas de uma das partes - pública ou privada -, as normas restritivas decorrentes desse direito devem respeitar a igualdade das exigências.

12 O autor contrapõe a leitura do Estado como "dominante" frente aos cidadãos à ideia do Estado democrático. Democracia significa a participação e a contribuição daqueles que compõe o Estado (HÄBERLE, Peter. La Garantia del Contenido Esencial de los Derechos Fundamentales em la Ley Fundamental de Bonn. p. 22-23; versão alemã: pp. 19-20).

${ }^{13}$ A "limitação", denominação que o autor prefere não utilizar, "oferece ao indivíduo o acesso ao parâmetro vigente de valores" (Idem, pp. 29-30; versão alemã: pp. 27-28). Neste raciocínio, também a lei penal serve ao titular do direito limitado, já que o ato de "desaprovar" conduz o indivíduo ao referido parâmetro de valor que rege a conduta na sociedade a qual participa (Idem, pp. 27-28; versão alemã: 25-26).

${ }^{14}$ Isso se dá porque a Constituição concedeu igual ou superior valor às regras gerais, o que as possibilita limitar os direitos fundamentais (Idem, p. 34; versão alemã: p. 32). O autor conclui pela possibilidade da mensuração de valor, nível e peso correspondente a cada direito fundamental a partir da reserva de lei; bem como pela possibilidade de proteção dos bens que não são mencionados nesta, por derivarem da função social do direito afetado ou das disposições de competências. O condicionamento recíproco dos direitos fundamentais e das leis gerais seria denominado "efeito de troca" e é de onde se deduz os limites e conteúdo dos direitos fundamentais, o que significa que "os direitos fundamentais e as leis gerais se limitam reciprocamente. Estão em uma relação 'contraposta'. Na interpretação de um direito fundamental tem-se que tomar em consideração os valores jurídicos protegidos através das leis gerais; na relação do efeito limitador sobre os direitos fundamentais das leis gerais tem-se que levar em conta o especial conteúdo axiológico do direito fundamental em questão" (Idem, p. 36; versão alemã: p. 34).

${ }^{15} \mathrm{O}$ jurista alemão demonstra afinidade pela teoria que apresenta a reserva de lei como limite imanente dos direitos fundamentais (Idem, pp. 51; versão alemã: p. 51). Constata, para além dessa premissa, que os limites imanentes decorrentes da essência dos direitos fundamentais e, só assim, poderão ser considerados limites aos direitos fundamentais, pois não são limitações externas, mas limites que expressam, desde o princípio, "a cada um deles o lugar que ocupa no conjunto constitucional" (Idem, p. 52; versão alemã: p. 51 ) - são determinados através da ponderação de bens. 
de ponderá-los quando colidentes, Häberle acentua a relação de concordância entre os direitos que é resultado de seu condicionamento recíproco. ${ }^{16}$ A ponderação seria uma forma de "equilíbrio", suportando a ideia de que o Direito Público pode, com ela, obter uma "unificação em uma situação global". ${ }^{17}$

Garantir o núcleo essencial seria determinar os limites dos direitos fundamentais conforme a sua essência, o que significa considerar seu papel no ordenamento através da ponderação de bens referenciada aos valores constitucionais. ${ }^{18}$ Os limites imanentes seriam limites que correspondem ao conteúdo essencial, de forma que constituem uma unidade ou a cercar tal essência. A ponderação de bens faz-se, então, necessária para a delimitação do conteúdo dos limites dos direitos fundamentais, e, portanto, do conteúdo do seu núcleo essencial. ${ }^{19}$ Recorre-se a tal instrumento em razão da impossibilidade de previsão, pelo legislador, de todas as situações as quais os direitos fundamentais, em virtude da existência de outros direitos ou bens, viriam a exigir a configuração de fronteiras que possibilitasse sua convivência. ${ }^{20}$ A delimitação dos limites correspondentes a cada direito fundamental dar-se-á de maneira diferente, em razão das diferenças de valor, níveis e posições ocupadas no ordenamento, bem como das circunstâncias de fato apresentadas para a atuação da ponderação.

Ao especificar o princípio da proporcionalidade, o autor o diferencia do princípio da ponderação de bens, sendo este pressuposto daquele. ${ }^{21}$ Como ponto em comum entre ambos, refere que se trata de princípios de natureza meramente formal. ${ }^{22}$

O princípio da proporcionalidade é visto como exigência de que os meios empregados para se chegar aos fins sejam adequados. Para tal, o legislador possui função de determinar "como" deve ser exercida a liberdade do titular do direito, ao contrário do entendimento do Tribunal Constitucional Federal Alemão, que estabelece uma maior liberdade de regulação ao legislador. ${ }^{23}$

\footnotetext{
${ }^{16}$ Critica a ideia de que os direitos fundamentais seriam restringidos ou relativizados pela ponderação de bens, pois, ao sustentar que os bens jurídicos estão reciprocamente protegidos, a lesão dos direitos fundamentais de um cidadão levaria à lesão dos direitos da comunidade, concluindo que "a igualdade de níveis dos direitos fundamentais e da garantia do Estado Social comporta que a ponderação de bens que resulta obrigada para a solução de conflitos no caso particular não conduza a absolutização da liberdade protegida pelo direito fundamental às custas da garantia do Estado Social, nem vice-versa" (HÄBERLE, Peter. La Garantia del Contenido Esencial de los Derechos Fundamentales em la Ley Fundamental de Bonn. p. 42; versão alemã: p.40).

${ }_{17}$ Idem, p. 40; versão alemã: p. 39.

18 Assim, acentua: "No conteúdo essencial dos direitos fundamentais se considera que estão, por exemplo, o princípio do Estado Social, os direitos (fundamentais) de terceiros e as leis penais" (Idem, p. 62; versão alemã: p. 61).

${ }_{19}$ Idem, p. 60; versão alemã: pp. 59-60.

${ }^{20}$ Idem, p. 55; versão alemã: p. 54.

${ }^{21}$ Idem, p. 67; versão alemã: p. 67.

${ }^{22}$ Idem, p. 68; versão alemã: p. 67.

${ }^{23}$ Idem, pp. 68-69; versão alemã: pp. 68-69.
} 
Diferentemente, Peter Häberle vincula o princípio da proporcionalidade a "considerações razoáveis do bem comum que permitam aparecer como 'adequada' uma delimitação de um direito fundamental.". ${ }^{24}$ Outras limitações só serão possíveis se os bens comuns forem de "nível superior e essencial importância", ${ }^{25}$ ou seja, extremamente necessárias. ${ }^{26}$

Häberle não concebe a ideia de limites absolutos, ${ }^{27}$ entendendo que a Constituição aspiraria um "resultado coletivo", o que não se confunde com a consideração de que os direitos fundamentais teriam caráter absoluto frente ao legislador ordinário - ideia defendida pelo autor -, ou seja, a intervenção legislativa na vida social tem caráter de exceção, devendo ser prezado o alcance do direito fundamental a todos, ou seja, "em geral". 28 A elevação dos direitos fundamentais a nível constitucional garante que esses não serão excetuados pelo legislador ordinário senão com base na própria Constituição. $^{29}$

Aponta para a importância da validade fática da norma e a participação desta na essência dos direitos, cuja força decorre de sua aplicação normativa e do seu exercício pelos titulares. ${ }^{30}$ A vinculação dos direito à realidade social garante a correlação dessa e do dever ser, o que os possibilita estar em permanente atualização por parte de seus titulares individuais $^{31}$ e que garante a sua não-relativização, já que não é possibilitado ao legislador pôr em perigo a "função social" dos direitos fundamentais. ${ }^{32}$

\footnotetext{
${ }^{24}$ HÄBERLE, Peter. La Garantia del Contenido Esencial de los Derechos Fundamentales em la Ley Fundamental de Bonn. p. 69; versão alemã: p. 68.

${ }^{25}$ Idem, p. 69; versão alemã: p. 69.

${ }^{26}$ Neste sentido, ressalva: "A medida que aumenta a intensidade da limitação da liberdade, tem que elevar correspondentemente as exigências para sua admissibilidade, o que para o princípio da proporcionalidade significa que, para uma limitação especialmente intensiva da liberdade, deve existir uma necessidade coativa" (Idem, p. 69; versão alemã: p. 69).

${ }^{27}$ Exemplifica com o Direito Penal, que seria um limite geral a todos os direitos fundamentais. A restrição só é possível com base em uma ideia de condicionamento recíproco dos direitos unidade da Constituição - não aceitando a ideia de antíteses, conforme já referido. Assim, complementa: "(...) a garantia do Estado Social, como parte constitutiva do conjunto constitucional, está em respeito aos direitos fundamentais em uma relação de condicionamento. A liberdade individual e a vinculação social estão, deste modo, em equilíbrio" (Idem, p. 48; versão alemã: p. 47).

${ }^{28}$ Idem, p. 49; versão alemã: p. 48-49. Concluindo: "Por meio do exercício dos direitos fundamentais se contribui substancialmente ao cumprimento da função social dos mesmos. A Constituição depende da contribuição ativa de cada indivíduo no âmbito vital que lhe corresponda" (Idem, ibidem).

${ }^{29}$ O que autoriza a restrição com reserva de lei e baseada em leis gerais, desde que tal restrição não faça com que o direito fundamental renuncie ao nível constitucional: "Observa-se que uma garantia 'absoluta' de tais normas de direitos fundamentais frente ao legislador por meio de seu caráter supralegal não é simplesmente possível, senão obrigatória" (Idem, p. 45; versão alemã: p. 44).

${ }^{30}$ Idem, pp. 46-47; versão alemã: pp. 45-46. Atribui a força da garantia da normatividade dos direitos fundamentais à idéia de "normalidade" (Idem, ibidem).

${ }_{31}$ Idem, p. 50; versão alemã: p. 49.

${ }^{32}$ Idem, p. 50; versão alemã: Idem, p. 49.
} 
Ao concluir tais ideias, o autor expõe a importância de uma determinação do conceito dos direitos fundamentais, ou seja, percebê-los conforme a dimensão pública subjetiva ou conforme a dimensão institucional e de sua relação com a teoria do núcleo essencial.

Defende que os direitos fundamentais possuem duas dimensões que convivem e se fortalecem, não havendo disparidade hierárquica e subordinação entre uma e outra. ${ }^{33}$ Tais dimensões seriam a dimensão jurídico individual $^{34}$ e a dimensão institucional, as quais ele denomina "âmbitos vitais" ou "relações objetivas", que se complementam de modo a compor o conjunto constitucional. ${ }^{35}$ Ao situar as duas dimensões como "dois pólos que estão na esfera do conceito do direito", o autor revela que a consideração dos direitos fundamentais unilateralmente como direitos subjetivo-liberais seria despreocupada da concepção de que a esfera objetiva do direito e a liberdade caminham juntas. ${ }^{36}$

É por meio do exercício do direito fundamental subjetivo que o indivíduo exerce seu direito institucional. ${ }^{37}$ A norma possui caráter dinâmico e inclui o fático. ${ }^{38}$ Assim, o indivíduo escolhe casar, escolhe a profissão, etc. A proteção

33 Paulatinamente, o TCFA vem, segundo o autor, considerando o duplo caráter dos direitos fundamentais. A exemplo disso, refere os casos de atribuição de dimensão subjetiva ao direito preceituado no artigo $6^{\circ}$ da LF - direito ao casamento e à família -, cuja dimensão institucional já era sabida. O tribunal alemão deduziu um "direito subjetivo de defesa" frente às intervenções do Estado que são desconformes ao direito dos pais a educar os filhos (HÄBERLE, Peter. La Garantia del Contenido Esencial de los Derechos Fundamentales em la Ley Fundamental de Bonn. p. 85; versão alemã: p. 83).

${ }^{34}$ Cujos titulares são indivíduos particulares ou grupos como associações e sindicatos.

35 Idem, p. 73-74; versão alemã: pp. 70-72. O autor retira da LF exemplos da dimensão institucional dos direitos fundamentais, quais sejam: os capítulos sobre "casamento e família"; "escola"; "ordenação econômica, agricultura e trabalho"; e conceitos tais como "ensino" (Idem, p. 75; versão alemã: p. 72). Salienta: "Ambos aspectos, o direito individual e o direito institucional, constituem, em seu conjunto, o 'direito fundamental'. Se fortalecem um ao outro. Os direitos constitucionais, considerados desde o ponto de vista de seus titulares, se manifestam como direitos público subjetivos e considerados a partir das relações vitais, se manifestam como institutos" (Idem, p. 74; versão alemã: p. 71).

${ }^{36}$ Para fundamentar o equilíbrio e interação das dimensões subjetiva e institucional dos direitos fundamentais, Peter Häberle recorre à filosofia, mais precisamente à Teoria das Instituições de Maurice Hauriou e o pensamento jurídico de Erich Kaufmann (Idem, pp. 76-81; versão alemã: pp. 73-79). Opõe-se à tese de Carl Schmitt, o qual defende a diferença unilateral dos direitos fundamentais como direitos individuais ou direitos institucionais, ideia que está, para o autor, superada.

37 Idem, p. 101; versão alemã: p. 100.

${ }^{38}$ Peter Häberle salienta a ideia do exercício dos direitos fundamentais prévio a sua positivação a partir da teoria de Maurice Hauriou - direitos fundamentais implantados no âmbito social -, em que tal processo é referente à identificação de comportamentos análogos e homogêneos exercidos por uma pluralidade de indivíduos - ocorrendo a transformação da "quantidade" em "qualidade"-, que dá origem a instituição dos direitos fundamentais. Assim, ao exemplificar, Peter Häberle refere: "A liberdade contratual só é um 'instituto' quando muitos indivíduos anônimos concluem contratos (...)" (Idem, p. 108; versão alemã: p. 108). Em concomitância, com referência à teoria do status de Jellinek, o autor considera os direitos fundamentais explicados como delimitadores do status do indivíduo no contexto do Estado, bem como nas mais diversas "relações vitais" - relações objetivas (Idem, p. 112; versão alemã: pp. 112-113). 
de âmbitos institucionais pela Constituição acarreta na proteção da liberdade do indivíduo e o livre desenvolvimento da personalidade, bem como impõe limites a essa mesma liberdade, no sentido de que o titular do direito estará submetido às regulamentações normativas da instituição a qual escolher fazer parte. ${ }^{39} \mathrm{Em}$ consequência a essa concepção, aponta para a possibilidade de limitações aos direitos fundamentais subjetivos em favor de direitos institucionais e, inversamente, desses direitos objetivos também devem surgir direitos subjetivos.

Reflete sobre as razões que remetem às interpretações unilaterais e às concepções errôneas a respeito dos problemas de Direito Público, barreiras que são impostas pelas ideias do voluntarismo - que concebe o direito como fruto de relações de vontade, entendendo que o contrato é o ponto de enfoque da análise jurídica $-;^{40}$ do direito natural racionalista - atribuição de "utilidade individualista" aos direitos institucionais e aos conceitos jurídicos, ${ }^{41}$ do subjetivismo, ${ }^{42}$ individualismo e liberalismo; ${ }^{43}$ do formalismo e do positivismo - que não abrem espaços para a interpretação sociológica e validade fática do Direito $-i^{.44}$ e da teoria dos direitos fundamentais e das garantias dos institutos, ambas de Carl Schmitt. ${ }^{45}$

A teoria do status permite a integração do indivíduo na sociedade, levando em conta "o elemento de cidadania ativa dos direitos fundamentais na relação com o Estado" (Idem, p. 113; versão alemã: p. 114).

${ }^{39}$ Refuta a ideia de que ambas as dimensões seriam contrapostas em forma de antinomias, considerando-as equilibradas e complementares uma a outra - âmbitos da vida que só têm sentido se considerados como "um todo" - ("direitos como um todo") (HÄBERLE, Peter. La Garantia del Contenido Esencial de los Derechos Fundamentales em la Ley Fundamental de Bonn. p. 99; versão alemã: pp. 97-98).

40 São partidários dessa teoria Jellinek e Laband (Idem, p. 88; versão alemã: p. 86-87). A manifestação da vontade leva às contraposições entre os indivíduos e entre estes e o Estado e a lei é vista como ato da vontade destes mesmos sujeitos, não havendo espaço para "idéias" e "substrato social", mas somente para seu formalismo. O subjetivismo é o "ponto de partida e chegada do Estado" e a vontade - categoria puramente formal - não dá espaço para determinação daquilo que é desejado em sentido material (Idem, ibidem; versão alemã: idem, ibidem).

${ }^{41} \mathrm{O}$ que teria levado Erich Kaufmann a desenvolver seu pensamento em contraposição a essa ideia (Idem, p. 91; versão alemã: p. 89)

${ }^{42} \mathrm{O}$ subjetivismo é próprio da Revolução Francesa e o pensamento desta época é baseado no rol de direitos fundamentais como defesa frente à atuação estatal. O pensamento de Maurice Hauriou tinha como principal objetivo a superação destes dogmas (Idem, p. 91; versão alemã: p. 90).

${ }_{43}$ É característica do individualismo e do liberalismo considerar os direitos fundamentais conforme a dimensão indivíduo-Estado, aos quais Erich Kaufmann se mostra como principal opositor ao refutar a ideia de redução das relações sociais a "direitos e obrigações" (Idem, p. 92; versão alemã: p. 90). Peter Häberle evidencia que o liberalismo é uma das causas do desconhecimento dos direitos fundamentais como direitos institucionais (Idem, p. 92; versão alemã: p. 90 ).

${ }^{44} \mathrm{O}$ formalismo e positivismo são, também, fruto do pensamento de Jellinek e Laband (Idem, pp. 92-93; versão alemã: p. 91).

${ }_{45}$ Carl Schmitt não entende os direitos fundamentais a partir da ideia do homem com a comunidade, mas do homem fora dela, adotando a ideia da liberdade e das garantias institucionais como antônimas. A liberdade para Carl Schmitt é aquela liberdade baseada na vontade, individual e contra o Estado em contraponto à liberdade no Estado e condescendente 
A partir da concepção da dúplice dimensão dos direitos fundamentais e o seu papel na vida social, o autor salienta a importância do legislador em "realizar" os direitos fundamentais. ${ }^{46}$ As limitações, ao contrário de restringirem as liberdades individuais, as proporcionam substrato de realidade social, pois o abuso da liberdade e a sua falta de limitação implicaria na falta de igualdade entre os cidadãos. ${ }^{47}$ As eventuais "restrições" são conformações e determinações do direito a partir de sua essência. ${ }^{48} \mathrm{Em}$ resumo, a autonomia dos direitos fundamentais - seu reconhecimento em dimensão subjetiva e institucional - e a ponderação de bens em concordância com as "garantias absolutas" os direitos fundamentais.

Na tentativa de defender a superação da ideia da contraposição entre o conteúdo dos direitos fundamentais e seus limites, Häberle observa que a concepção tradicional da legislação de reserva é firmada pelo entendimento de que as restrições suprimiriam os direitos fundamentais. ${ }^{50}$ Tal opinião entende incompatível a existência da garantia de inviolabilidade dos direitos da pessoa humana - disposto no artigo 1 da LF - com a concomitante previsão da necessidade das restrições para conformar a liberdade e a propriedade. A explicação do autor é no sentido de que a referida contradição no ordenamento só existiria se as restrições aos direitos forem consideradas como originadas "desde fora", concepção que recusa exaustivamente na obra por acreditar numa ideia de restrições imanentes e conforme a essência do direito. ${ }^{51}$

com os interesses gerais. A atividade do legislador é tida como excepcional (Idem, pp. 93-96; versão alemã: pp. 92-95)

${ }^{46}$ Destaca o papel significante do legislador, qual seja: "Constituir os singulares âmbitos vitais; proporcionar aos direitos fundamentais uma existência duradoura; criar os complexos normativos - necessários, evidentemente, com uma diversa 'densidade' em cada caso - que fazem realidade a idéia de direitos fundamentais nos singulares âmbitos sociais; regular bens jurídicos - por exemplo, os tipos de contratos no Direito civil, as diferentes regulamentações da profissão e as formações sociais - que são constitutivos para os direitos fundamentais como institutos e não constituem simplesmente uma 'transformação' dos direitos fundamentais, senão sua 'realização efetiva'" (HÄBERLE, Peter. La Garantia del Contenido Esencial de los Derechos Fundamentales em la Ley Fundamental de Bonn. p.115; versão alemã: p. 116). A dimensão institucional dos direitos fundamentais tem duplo caráter frente ao legislador: de autorização para que ele possa limitar as liberdades - e de limite - a dimensão institucional dos direitos não pode ser ameaçada (Idem, p. 121; versão alemã: p. 122).

${ }^{47}$ Faz-se da restrição a possibilidade do exercício do direito fundamental por uma pluralidade de indivíduos (Idem, pp. 116-120; versão alemã: pp. 117-122).

${ }_{48}$ Idem, p. 119; versão alemã: pp.119-120.

${ }^{49} \mathrm{~A}$ ponderação é a "forma de regular os âmbitos vitais protegidos pelos direitos fundamentais "(Idem, p. 123; versão alemã: p.125).

${ }^{50} \mathrm{O}$ autor expõe a doutrina majoritária, em especial as ideias de Erich Fechner, no sentido de que a reserva de lei negaria a realização dos direitos fundamentais e autorizaria verdadeiras intervenções no conteúdo de tais direitos (Idem, pp. 128-130; versão alemã: pp. 127-130).

${ }^{51}$ Idem, pp. 128-129; versão alemã: pp. 127-128. A ideia de que os limites à propriedade concretizam a liberdade e são consequências do seu conceito é provinda, em especial, do direito alemão. Peter Häberle ressalva, inclusive, que o Tribunal Federal alemão, em tempos 
As causas que dão origem às linhas do pensamento tradicional de contraposição entre a legislação de reserva e direitos fundamentais são amplamente discriminadas e analisadas por Peter Häberle, que as atribui à forma como se concebe o direito natural. É tributário dos adeptos ao jusnaturalismo o pensamento de que a liberdade de ação seria direito fundamental negativo e subjetivo, ${ }^{52}$ com caráter ilimitado e "natural". 53 Contrariamente, o jurista alemão não aceita que o direito natural seja extrajurídico, mas sim elemento estrutural e componente objetivo do direito vigente, incluído nesse como fundamento de legitimidade. ${ }^{54}$ Ademais, a forma como tradicionalmente o legislador fora visto no direito alemão "inimigo da liberdade do cidadão" $-;,{ }^{.5}$ o desconhecimento de que a conformação da liberdade com a dimensão institucional leva a garantia dos direitos fundamentais ${ }^{56}$ e a desconsideração da função interpretativa que abarque os conteúdos jurídicos previamente existentes- ${ }^{57}$ método históricoespiritual -, são causas da que levariam a minimização e resistência à função interventiva do legislador e a descrença na força legitimatória que os direitos fundamentais ganham com o passar do tempo. ${ }^{58}$ Considera, também, que a

recentes, "fala de uma conformação legislativa concreta da vinculação social da liberdade imóvel" (Idem, p. 130; versão alemã: pp. 129-130). Entretanto, ainda hoje - ressalva-se que a obra foi publicada no ano de 1962 - e apesar dos avanços considerados pelo autor, conforme a concepção majoritária da doutrina e do TCFA, a reserva de lei deve atender aos interesses da comunidade e realizar as exigências do Estado e, por isso, o conteúdo essencial dos direitos fundamentais está ligado primeiramente à comunidade e não ao individuo de forma particular, opinião a que Peter Häberle não está de acordo (Idem, p. 134; versão alemã: pp. 133-134). Para o autor, os limites imanentes e o conteúdo desses direitos teriam o mesmo significado.

${ }^{52}$ O que não contempla a correlação dos direitos individuais e institucionais e contrapõe a legislação ao direito de exercer a liberdade, pois se trataria da "liberdade de direito" (HÄBERLE, Peter. La Garantia del Contenido Esencial de los Derechos Fundamentales em la Ley Fundamental de Bonn. pp. 140-143; versão alemã: pp. 150-154), “(..) pelo que se produz a impressão de que a liberdade é ausência de direito" (Idem,p. 141; versão alemã: p. 151). Peter Häberle salienta que essa idéia de liberdade negativa provém do entendimento do direito somente como "mandato e proibição", citando os entendimentos de Kelsen - da liberdade somente em sua dimensão negativa - e Carl Schmitt e sua escola - "liberdade 'liberal'" em que o Estado, a comunidade e o direito estão separados (Idem, ibidem; versão alemã: pp. 150-151). Ainda, analisa a visão da liberdade a partir das ideias Jellinek do "status passivus", que refere que toda obediência do indivíduo ao Estado é submissão e manifestação de ausência de personalidade (Idem, p. 143; versão alemã: pp. 153-154).

${ }^{53}$ Idem, pp. 135- 139; versão alemã: pp. 145-150.

${ }^{54}$ Idem, p. 136; versão alemã: p. 146.

${ }^{55}$ Idem, p. 151; versão alemã: p. 163.

${ }^{56}$ Idem, pp. 140 e 152; versão alemã: pp. 150 e 163-164. Que, consequentemente, leva ao desconhecimento de que a conformação necessita também de complexos normativos e de um órgão que os concretizem (Idem, pp. 141 e 152-153; versão alemã: pp. 151 e 163-165).

57 Idem, p. 158-159; versão alemã: pp. 170-171. As leis ordinárias anteriores a Constituição como, por exemplo, o Código Civil e o Código Penal, servem de "limites imanentes à liberdade geral de ação da Constituição". O autor preocupa-se em demonstrar que detalhes importantes do direito constitucional foram tratados primeiramente por leis ordinárias (Idem, p. 159-160; versão alemã: pp. 171-173).

${ }^{58}$ A recepção de conteúdos previamente existentes manifesta-se no catálogo de direitos fundamentais em razão de que a nova Constituição apenas adota "cláusulas gerais" e "esquematiza" 
concepção de Anshütz de "cláusula de intervenção" - ${ }^{59}$ toda e qualquer lei em sentido material limita e restringe a liberdade e a propriedade do indivíduo - ${ }^{60}$ teria influenciado a literatura alemã antiga no sentido da não aceitação da reserva de conformação, ${ }^{61}$ em razão daquela ideia estar próxima à teoria jusnaturalista - por pressupor uma "fixação social de limites", ideia subjacente ao "direito natural abstrato"-. ${ }^{62}$

Para Peter Häberle tal entendimento da imagem limitadora da atuação legislativa não procede já que o indivíduo não vive sem a sociedade e a ela vincula-se. Disto decorre que "restrição" da liberdade não estaria ligada a ideia de sacrifício, mas faz parte de um contexto de convivência. O jurista entende a ciência jurídica a partir da procura por soluções das antinomias como forma de atingir o equilíbrio e não apenas como identificadora dos conflitos. A busca da finalidade da ideia de "intervenção" e "restrição" perde o sentido quando conceituadas como antinomias existentes entre a comunidade e a liberdade, pois ignora o fato de que muitas destas intervenções decorrem de interesses dos cidadãos.

Consequentemente, preocupa-se com o reconhecimento da atribuição jurídico-constitucional do legislador como forma de limite as suas funções. ${ }^{63}$ O legislador, ao cumprir sua atribuição constitucional, deve reconhecer o duplo conteúdo das garantias $-{ }^{64}$ conformando-as e limitando-as para que

os âmbitos vitais, respeitando o conteúdo que diz respeito ao reflexo das transformações e realidades sociais: "Em geral, só partes específicas de uma obra constituinte são expressão de uma nova ordem revolucionária e uma nova criação normativa" (Idem, p. 156; versão alemã: p. 168). Exemplifica com momentos históricos das constituições alemãs, as quais caracteriza como "ricas em recepções", enfatizando a Constituição de Weimar - segundo o autor, nada criativa - a qual teve larga participação do legislador ordinário (Idem, p. 161; versão alemã: p. 173).

59 Idem, p. 144; versão alemã: pp. 154-155.

${ }^{60}$ HÄBERLE, Peter. La Garantia del Contenido Esencial de los Derechos Fundamentales em la Ley Fundamental de Bonn. pp. 144-145; versão alemã: p. 154-156. Conforme Anschütz, o conceito de direito é reduzido nos conceitos de coerção, limites e delimitação da vontade individual sendo, esta última, submetida ao poder e vontade do Estado que a obstaculariza e a ela contrapõe-se (Idem, p. 144; versão alemã: pp. 155-156). Tal manifestação de vontade estatal pode ser observada como ilimitada e "exteriorizada como exercício do poder" (Idem, pp. 145-146; versão alemã: pp. 154-157).

${ }^{61}$ Idem, p. 150; versão alemã: p. 162.

62 Idem, p. 148; versão alemã: p. 159. As maiores críticas do autor são no sentido de que Anschütz não diferencia os tipos de leis que possam ser consideradas restritivas e quais não. Além disso, não dá atenção às normas interpretativas, normas de caráter autorizador e normas do direito privado, as quais têm natureza propriamente de coordenação (Idem, pp. 146-147; versão alemã: pp.157-159).

63 Idem, pp. 168-169; versão alemã: pp. 180-182. Peter Häberle refere que a função do legislador de conformação dos direitos fundamentais com a realidade decorre do artigo 20 da LF (Idem, pp. 176-177; versão alemã: pp. 189-190).

${ }^{64}$ É importante também que se reconheça o duplo conteúdo das garantias no sentido de limitar a função legislativa - o duplo sentido das garantias seria sua aceitação como "limites" e como "mandato ao legislador de conformar" cada direito fundamental individualmente - ao referido encargo jurídico-constitucional (Idem, p. 169; versão alemã: p. 182). 
coexistam na ordem jurídica $-{ }^{65}$ e seguir seus ideais, ${ }^{66}$ possibilitando aos titulares dos direitos condições de exercê-las. ${ }^{67}$

A propósito da forma utilizada pelo legislador para delimitar o direito fundamental frente a bens jurídicos de igual ou superior valor, atribui, conforme já referido, grande valia ao princípio da ponderação de bens. ${ }^{68}$ A importância da reserva de lei é que ela gera a possibilidade de o legislador efetuar a ponderação de bens na ordem constitucional, que é permitida e a serviço da própria Constituição eis que se trata de instituto nela fixado sendo assim, reafirma-a - e não tem poder de regulamentar o "conteúdo em sentido próprio" dos direitos. ${ }^{69}$ Tal atribuição concedida ao legislador é consequência da natureza das cláusulas constitucionais - "cláusulas gerais" - passíveis de serem alteradas e acomodadas ao longo do tempo, ${ }^{70}$ não há a necessidade de reforma constitucional para a mudança de

\footnotetext{
${ }^{65}$ Concretização esta que se dá conforme a essência dos direitos e com a finalidade de "fazer realidade uma parte do conteúdo essencial de tais direitos" (Idem, p. 171; versão alemã: p. 183). ${ }^{66}$ O legislador deve seguir o "mandado de conformação contido nos direitos fundamentais" que o proíbe de lesioná-los e o incumbe de seguir o "ideal" de tais direitos individualmente, podendo a não conformação entre a garantia do direito e seu "telos" acarretar lesão aos direitos fundamentais (Idem, p. 170; versão alemã: p. 182).

${ }^{67}$ A promulgação dos "detalhes" pelo legislador é obrigatória, função sem a qual os direitos fundamentais permaneceriam no campo do Dever Ser - ou, utilizando-se a expressão do autor, "no papel" (Idem, p. 171; versão alemã: p. 184). A garantia constitucional dos direitos fundamentais não é garantia de que eles se tornem realidade (HÄBERLE, Peter. La Garantia del Contenido Esencial de los Derechos Fundamentales em la Ley Fundamental de Bonn. p. 172; versão alemã: p. 185). O autor salienta que a LF elegeu outras formas de tratar o problema das intervenções no âmbito dos direitos fundamentais que não se tratam dos já superados conceitos de "limitação" ou "restrição", deixando clara a intenção de imanência de limites, já que, nestas disposições, é concedido ao titular do direito a disponibilidade de "invocar seu direito", com a ressalva de que não ameacem ou lesionem outros direitos ou bens jurídicos (Idem, p. 215; versão alemã: p. 231).

${ }^{68}$ Idem, p. 175; versão alemã: p. 188. O autor menciona o direito penal - material e processual - como forma de ilustrar tal possibilidade. Há quem considere as disposições de direito penal como restrição da liberdade, mas, como defende o autor, não haveria garantias de direitos fundamentais sem regulamentações de natureza penal e, no lugar de liberdade, ter-se-ia arbitrariedade e força. Peter Häberle demonstra que, através da proporcionalidade, o legislador saberá em quais direitos intervir e como se dará essa intervenção penal, de modo a assegurar a observância dos direitos e não puramente limitá-los (Idem, pp. 175-176; versão alemã: p. 189).

${ }^{69}$ Idem, p. 189; versão alemã: p. 203.

${ }^{70}$ Idem, p. 203; versão alemã: p. 218. A possibilidade de mudanças dos direitos fundamentais ao longo do tempo - decorrentes das mudanças ocorridas na sociedade e de sua correlação com a função institucional - possibilita a concepção do catálogo constitucional dos direitos fundamentais dar-se de forma "geral", cabendo a especificação do âmbito de tais direitos à legislação ordinária. Os direitos fundamentais são normas as quais, "apesar da mesma literalidade, acabam submetidos a mudanças materiais": “(...) as cláusulas gerais não se modificam como tais em seu conteúdo, senão são as concretizações que têm lugar com fundamento em tais cláusulas gerais - que se manifestam, no âmbito dos direitos fundamentais, através da legislação de reserva e da jurisprudência constitucional - as quais estão expostas à mutação de conteúdo" (Idem, p. 203; versão alemã: p. 218). O autor tem o cuidado de referir que tais mudanças não são características de todas as normas constitucionais, ao passo que deve ser mantido o conteúdo estático, que é qualidade das normas institucionais.
} 
interpretação e atribuição de limitações aos direitos fundamentais. ${ }^{71} A$ função de conformação do legislador é, na concepção do autor, obrigatória - e não apenas autorizada pela reserva de lei -, conclusão que o permite exercê-la independentemente de reserva legal.

Em que pese a função legislativa ser facilitadora do usufruto das liberdades - e não desencadeadora do "fim das liberdades"-, o autor acentua que, mesmo no campo das limitações e regulamentações legislativas, há esferas que não estão a dispor do legislador. ${ }^{73} \mathrm{~A}$ partir da ideia de direito como "ordenação limitada", Häberle diz da importância dos limites à função regularizadora do legislador. ${ }^{74}$ Salienta que o conteúdo do direito objeto da conformação, limitação e criação pelo legislador ordinário não ganha força constitucional. O legislador ordinário somente tem capacidade de adaptar e modificar os direitos conforme as necessidades reais que surgem perante o seu exercício. ${ }^{75}$

Ressalva-se que não só os direitos fundamentais em seu conteúdo sofrem modificações, mas também seu núcleo essencial. ${ }^{76} \mathrm{O}$ caso é que tais mudanças não são somente necessárias, como obrigatórias, pois sem elas a Constituição correria o risco de perda da validade de seus conteúdos essenciais em decorrência da sua incompatibilidade com a atualização social dos valores. ${ }^{77}$

O que deve ficar claro é que, conforme a linha de pensamento exposta pelo autor, o legislador, ao atribuir significado às cláusulas gerais, não tem condições de fazê-lo de uma vez para sempre. ${ }^{78}$ Eventualmente, a legislação de reserva pode ser pioneira em relação a certas modificações, possibilitando, futuramente, que a Constituição efetue as mudanças, o que a atribui o papel

\footnotetext{
${ }^{71}$ HÄBERLE, Peter. La Garantia del Contenido Esencial de los Derechos Fundamentales em la Ley Fundamental de Bonn. p. 178; versão alemã: p. 191. A Constituição, ao atribuir força criativa ao legislador, pode "atender às exigências de uma realidade social em desenvolvimento sem que seja necessária a reforma constitucional" (Idem, p. 178; versão alemã: p. 191).

${ }^{72}$ Idem, p. 180; versão alemã: pp. 195-196. Assim aconteceria, por exemplo, com a disposição constitucional do casamento e da família - artigo 6 da LF alemã - que autorizaria e reclamaria, na visão do autor, a conformação legislativa para seu exercício, em que pese o artigo não prescrever a reserva (Idem, p. 180; versão alemã: pp. 195-196). Isso se dá porque o conteúdo dos direito, mesmo com sua conformação legislativa, continua o mesmo (Idem, p. 187; versão alemã: p. 201). Salienta que não há lógica em falar-se de lesões ao conteúdo essencial do direito por parte do legislador ordinário, pois esse apenas exerce papel que é admissível constitucionalmente.

${ }^{73}$ HÄBERLE, Peter. La Garantia del Contenido Esencial de los Derechos Fundamentales em la Ley Fundamental de Bonn. pp. 182 e ss; versão alemã: pp. 196 e ss. A obrigação de regulamentar os institutos constitucionalmente estabelecidos não permite a restrição de forma que não reste espaço para o exercício da liberdade (Idem, ibidem).

74 Idem, p. 184; versão alemã: p. 197.

${ }^{75}$ Idem, pp. 197-198; versão alemã: p. 212.

${ }^{76}$ Idem, pp. 203-204; versão alemã: pp. 218-219.

77 Idem, p. 203; versão alemã: pp. 218-219.

${ }^{78}$ Idem, p. 203; versão alemã: p. 218.
} 
de influenciar materialmente a Constituição contando que seja uma "mudança somente com limites e em longos períodos de tempo". ${ }^{79}$

Ao final da obra e estabelecendo suas linhas conclusivas, Peter Häberle acentua a desnecessidade da preceituação expressa garantido a intangibilidade do núcleo essencial dos direitos, já que tal garantia seria imprescindível somente no caso de a legislação ordinária ser considerada em oposição a Constituição - e, portanto, impositora de seus "limites" -, o que faria com que o artigo 19.2 LF tivesse plena aplicação e fizesse as vezes de garantia irrenunciável. ${ }^{80} \mathrm{O}$ caso é que Häberle defende a garantia do núcleo essencial, disposta no artigo 19.2 da LF, como norma vazia, motivado pelo fato de que o seu conteúdo estaria presente no ordenamento constitucional mesmo sem positivação, em decorrência da existência de uma confluência de princípios que o comporiam. ${ }^{81}$ Mesmo com tais considerações, reconhece que a importância do preceito ser expresso na Constituição seria a garantia da segurança jurídica em virtude de facilitar sua aplicação e respeito. ${ }^{82}$ Atribui, portanto, um significado "atualmente declarativo", mas "latentemente constitutivo" à norma.

O artigo 19.2 da LF teve sua origem em uma época em que se desejava proteger os direitos fundamentais da ação do legislador. ${ }^{84}$ É qualificado como "garantia institucional", pois que serve para evitar abusos e é complementário às liberdades $-^{85}$ o autor acaba por concluir que tal conceituação poderia ser feita somente com a concepção de que cada direito fundamental é composto também por uma dimensão institucional $-{ }^{86} \mathrm{e}$ tem caráter declarativo.

Diante do esboço da obra chega-se a diversas conclusões que serão expostas a seguir. Parte-se da ideia largamente defendida pelo autor ao longo do texto da conformação da dimensão institucional com a dimensão subjetiva dos direitos para fazer as próximas considerações, salientando os motivos pelos quais levam Peter Häberle a conceber os direitos fundamentais dessa forma e a teoria de restrição dos direitos cujas ideias ele é partidário.

\footnotetext{
79 Idem, p. 204; versão alemã: pp. 219-220. Cumpre salientar que o autor não concede ao legislador de reserva poderes que, desde o início, sejam criativos em si, pois levaria a abusos e à ocupação do lugar da Constituição pela legislação. A legislação continua vinculada a Constituição.

${ }^{80}$ HÄBERLE, Peter. La Garantia del Contenido Esencial de los Derechos Fundamentales em la Ley Fundamental de Bonn. pp. 219-220; versão alemã: pp. 234-235.

${ }^{81}$ Idem, p. 219; versão alemã: p. 235.

${ }^{82}$ Idem, p. 220; versão alemã: p. 236. Considera que dessa forma a Constituição deixou claramente expressa a impossibilidade de "esvaziamento dos direitos fundamentais" (Idem, p. 220; versão alemã: p. 236).

83 Idem, p. 220; versão alemã: p. 235.

${ }^{84}$ Idem, p. 221; versão alemã: pp. 236-237.

${ }^{85}$ Idem, p. 222; versão alemã: p. 237.

${ }^{86}$ Idem, p. 221; versão alemã: pp. 236-237.
} 


\section{CRÍTICA ÀS IDEIAS DO AUTOR}

\subsection{Breve Introdução ao Pensamento do Autor}

Comentar este livro de Häberle exige situá-lo no conjunto da obra do autor, de modo a destacar traços fortes do seu pensamento.

Peter Häberle propõe a ideia de "constituição pluralista". ${ }^{87}$ A constituição do pluralismo apóia-se em um conjunto diverso de ideias e interesses, pois é pensada de forma democrática, ${ }^{88}$ e é reflexo de uma sociedade que tem coesão de pensamentos culturais e, por isso, concebe a Constituição não somente como texto jurídico, mas comprometida com contexto cultural do qual faz parte. ${ }^{89} \mathrm{~A}$ sintonia plena entre o normativo e o real ${ }^{90}$ constitui o que o autor denomina de "constituição viva", ${ }^{91}$ questão que se mostra amplamente analisada na presente obra quando atenta para a interpretação que leve em conta a dupla dimensão dos direitos fundamentais - a subjetiva e a institucional -. Tal interpretação é feita pela sociedade e todos os órgãos estatais, possibilitando que todo o titular de direito que o exercita acabe por viver a realidade normativa e, assim, é capaz de interpretar a norma de direito fundamental. ${ }^{92} \mathrm{~A}$ intenção do autor é, portanto, firmar a ideia de Constituição democrática ${ }^{93}$ que, por assim o ser e em atenção ao

\footnotetext{
87 HÄBERLE, Peter. Grundrechtsgeltung und Grundrechtsinterpretation im Verfassungsstaat in $J Z, 1989,20$, p. 918.

${ }^{88}$ SEGRADO, Francisco Fernandéz in HÄBERLE, Peter. La Garantia del Contenido Esencial de los Derechos Fundamentales em la Ley Fundamental de Bonn. Estudo preliminar, p. XLIII.

${ }^{89}$ SEGRADO, Francisco Fernandéz in HÄBERLE, Peter. La Garantia del Contenido Esencial de los Derechos Fundamentales em la Ley Fundamental de Bonn. p. XLIX. A "onipresença" dos direitos fundamentais no Estado Constitucional impõe a releitura do conceito tradicional de validade dos direitos, que Peter Häberle entende ter evoluído para um conceito de "cultura de direitos fundamentais" (Grundrechtskultur) (HÄBERLE, Peter. Grundrechtsgeltung und Grundrechtsinterpretation im Verfassungsstaat. p. 915) Tal processo cultural desencadeia-se através do papel de todos os inseridos na sociedade na interpretação e realização dos direitos, o que resulta em uma validade que supera a esfera jurídica e é firmada também no Real (Idem, p. 916).

${ }_{90}$ A ideia de interpretação normativa ligada à realidade embasa também o conceito de "sociedade aberta dos intérpretes da constituição", que o autor fundamenta em artigo intitulado Die offene Gesellschaft der Verfassungsinterpreten. A garantia de realidade conjugada ao texto normativo só é alcançada com a pluralidade de intérpretes, que possibilitam a inserção de sua "sinceridade e espontaneidade" no processo interpretativo, alheias à disciplina metodológica jurídica que, por sua vez, também é parte do processo através do contributo dos juristas (HÄBERLE, Peter. Die offene Gesellschaft der Verfassungsinterpreten in JZ, 1975, 10. p. 303).

${ }_{1}$ SEGRADO, Francisco Fernandéz. Op. cit., p. XLII.

${ }^{92}$ A interpretação normativa não é tarefa apenas dos poderes estatais instituídos constitucionalmente para tal, mas também daqueles que "vivem" a norma - "interpretação democrática" - direta ou indiretamente (HÄBERLE, Peter. Die offene Gesellschaft der Verfassungsinterpreten. p. 297; HÄBERLE, Peter. Grundrechtsgeltung und Grundrechtsinterpretation im Verfassungsstaat. p. 918). $\mathrm{O}$ autor tenta deixar claro que a unidade da Constituição baseia-se no processo interpretativo conjunto da sociedade enquanto sujeitos normativos, dos órgãos públicos e da ciência jurídica, e que tal processo proporciona legitimidade jurídica que deriva da atualização constante advinda da prática social (HÄBERLE, Peter. Die offene Gesellschaft der Verfassungsinterpreten. p. 301). ${ }_{93} \mathrm{O}$ conceito de democracia trabalhado por Peter Häberle não é somente formal baseado nas decisões dos órgãos competentes legitimados pelo voto dos cidadãos, mas que "desenvolve-se (...) em uma forma de processo público plural cotidianamente prático e político, em especial na
} 
argumento de que os limites imanariam e estariam em harmonia com próprio direito, impossibilita que seus limites sejam contrários aos direitos fundamentais.

A partir dessas premissas, a ideia de que a forma de salvaguardar a liberdade não seria tornando-a ilimitada, mas limitando-a, se faz coerente ao restante dos seus pensamentos. A falta de fixação de fronteiras à liberdade dos homens levaria ao caos social, de forma que o limite que provém do seu conteúdo é a garantia de que se poderá executá-la e de que os outros sujeitos de direito também a exercerão, sem que entrem em conflito e sem que haja arbitrariedade e abuso de poder de uns sob os outros. E não só. Tais limites são parte da essência da liberdade - o que os legitima sem que possam ser concebidos como "restrições" a elas - já que são pressupostos de seu exercício. ${ }^{94}$

Tal limitação à liberdade é aceita em razão da forma como o autor concebe a atuação do Estado frente aos direitos fundamentais. Deixa claro em muitas passagens desta obra que a visão do Estado que restringe e coíbe o exercício das garantias e direitos fundamentais - entendimento firmado na Revolução Francesa -, onde o cidadão é titular de direitos de cunho negativo - direitos que se manifestam de forma defensiva frente ao poder do Estado, visão que contempla a redução dos direito a uma relação unidimensional ${ }^{95}$, está ultrapassada. A dupla dimensão dos direitos fundamentais - direitos subjetivos e em consonância com a realidade social - é amplamente demonstrada e analisada em seu trabalho.

2.2 Concepção do Catálogo de Direitos como Normas Princípios ou Normas Regras e a Adequação do Pensamento a uma Teoria de Limitação dos Direitos Fundamentais

A concepção da natureza das normas do catálogo de direitos fundamentais como normas que veiculam princípios ou normas que veiculam regras e do seu respectivo âmbito de proteção - diferenciação entre âmbito de proteção amplo ou restrito - está intimamente ligada à teoria que discute a possibilidade da imposição de limites ou não aos direitos constitucionalmente garantidos. $^{96}$

realização dos direitos fundamentais, freqüentemente mencionado na 'dimensão (Seite) democrática' dos direitos fundamentais (...)" (HÄBERLE, Peter. Die offene Gesellschaft der Verfassungsinterpreten. pp. 301-302).

${ }^{94}$ Os direitos fundamentais e a legislação que os regula formam uma "unidade" (HÄBERLE, Peter. Grundrechte und parlamentarische Gesetzgebung im Verfassungsstaat - das Beispiel des deutschen Grundgesetzes in AöR, 114, 3, 1989. p. 376).

${ }^{95}$ SEGRADO, Francisco Fernandéz in HÄBERLE, Peter. La Garantia del Contenido Esencial de los Derechos Fundamentales em la Ley Fundamental de Bonn. p. LIV.

${ }^{96}$ Excetuam-se as opiniões de Pieroth e Schlinck (PIEROTH, Bodo; SCHLINCK, Bernhard. Grundrechte, Staatsrecht II. 25. ed., Heidelberg: C.F.Müller, 2009. p. 60) e Virgílio da Silva, que entende não ser esta uma "ligação necessária nem freqüente" (SILVA, Virgílio Afonso da. Direitos Fundamentais: conteúdo essencial, restrições e eficácia. São Paulo: Malheiros, 2009. p. 158). Ao contrário, Ingo Sarlet trata das diferenças entre uma e outra teoria vinculando diretamente a concepção de cada uma delas ao âmbito restrito ou amplo de proteção do direito 
A possibilidade de restrição dos direitos é afastada de plano pelos simpatizantes da Teoria Interna. Os direitos fundamentais nasceriam com suas limitações, ${ }^{97}$ as quais são denominadas limites imanentes, cuja existência estaria implícita e formaria uma unidade junto ao conteúdo de cada direito fundamental. ${ }^{98}$ Partindo de uma visão restrita de âmbito de proteção, ${ }^{99}$ a lógica da limitação interna é que o "direito verdadeiro" é aquele que, após o raciocínio de interpretação, ${ }^{100}$ sobressai, e o que anteriormente se apresentava era conteúdo inexistente do direito. ${ }^{101}$ Os direitos fundamentais teriam a natureza de regras $e^{102}$ ao entrarem aparentemente em colisão com outros direitos, a solução dar-se-ia pelo raciocínio de inclusão ou não das atuações no âmbito de proteção do direito. No plano abstrato, os limites são definidos pela Constituição, implícita ou explicitamente, e a lei que regulamenta o direito não é restritiva, mas declarativa de limites revela ou concretiza limites já previstos,$-{ }^{103}$ mesmo quando for de natureza proibitiva - ${ }^{104}$ ou seja, o problema não chega a ser perspectivado sob o olhar da restrição, pois se trata de indagar previamente o conteúdo do direito, delimitá-lo, ${ }^{105}$ não sendo concebida a existência de restrições não expressamente autorizadas aos direitos. ${ }^{106}$

(SARLET, Ingo Wolfgang. A Eficácia dos Direitos Fundamentais. 10. ed., Porto Alegre: Livraria do Advogado, 2009. p. 388). Neste sentido, também: CANOTILHO, José Joaquim Gomes. Dogmática de Direitos Fundamentais e Direito Privado in Estudos sobre Direitos Fundamentais, 2. ed., Coimbra: Coimbra Editora, 2008. p. 213.

${ }_{97}$ CANOTILHO, José Joaquim Gomes. Dogmática de Direitos Fundamentais e Direito Privado, p. 201; SARLET, Ingo Wolfgang. Op. cit., p. 388.

${ }_{98}$ BOROWSKI, Martin. La Restricción de los Derechos Fundamentales in Revista Española de Derecho Constitucional. Madrid: $n^{\circ}$ 59, mayo/ago., 2000. p. 32; Op. Cit., p. 388; SILVA, Virgílio Afonso da. Direitos Fundamentais. p. 129.

${ }_{99}$ CANOTILHO, José Joaquim Gomes. Op. Cit., p. 231-233.

${ }^{100}$ A justificação dos conflitos entre direitos é, portanto, resolvida em um exercício de mera interpretação e o uso da ponderação é dispensado em face da inexistência de um verdadeiro conflito e da impossibilidade de restrições externas - limitações são inerentes à estrutura do direito e decorrem de sua existência, são apenas declaradas, concretizadas, explicitadas ou interpretadas (NOVAIS, Jorge Reis. As Restrições aos Direitos Fundamentais não expressamente autorizadas pela Constituição. Coimbra: Coimbra editora, 2003. pp. 438- 440).

${ }^{101}$ Isto acontece porque não há direito prima facie e direito definitivo, mas apenas um direito e seus limites interpretáveis; direito e "não-direito" (SARLET, Ingo Wolfgang. Op. cit., p. 392); ou "conteúdo verdadeiro" e "conteúdo aparente" (BOROWSKI, Martin. Op. cit., p. 33).

102 BOROWSKI, Martin. Op. cit., pp. 39-40; ALEXY, Robert. Teoria dos Direitos Fundamentais. Trad. Virgílio Afonso da Silva. São Paulo: Malheiros, 2008. p. 278; SILVA, Virgílio Afonso da. Op. cit., p. 129.

${ }^{103}$ NOVAIS, Jorge Reis. Op. cit., p. 392.

104 SILVA, Virgílio Afonso da. Op. Cit., pp. 131 e 133. Ou seja, a proibição não é proibição da liberdade, mas proibição por mera não-proteção (Idem, p. 133).

${ }^{105}$ NOVAIS, Jorge Reis. Op. cit., p. 396. A delimitação é suficiente para resolver o problema das restrições não expressamente autorizadas. A falta de previsão, pelo legislador constitucional, da possibilidade de restrição é entendida, pelos defensores da teoria, como uma "proibição absoluta da restrição deste tipo de direitos" (Idem, p. 417), o que exclui a possibilidade de aferição das circunstâncias e necessidades momentâneas que possam aparecer quando da ocorrência de uma colisão (Idem, p. 418).

${ }^{106}$ Idem, p. 390. 
A liberdade é, nestes casos, vista como liberdade aliada à ideia de direito e de ordem jurídica e esses, enquanto elementos de integração das liberdades, possuem uma coerência interna suficiente para a extração prévia de condutas do âmbito de proteção de cada direito fundamental. ${ }^{107}$

A Teoria Externa parte do pressuposto da independência e autonomia dos direitos e de suas restrições. ${ }^{108}$ Mesmo que não seja entendimento unânime ${ }^{109}$ a teoria externa das restrições de direitos fundamentais é fundamentada nos pressupostos dogmáticos da teoria dos princípios. ${ }^{110}$ Assim, em uma primeira análise, se diferenciam os direitos em normas regras ou normas princípios. ${ }^{111}$ Os direitos fundamentais veiculados por regras são estruturas fechadas cujo papel do aplicador é limitado em termos de interpretação e a aplicação dar-se-á pelo método da subsunção. Contrariamente, no caso dos princípios, os direitos fundamentais são lidos, prima facie, como "presunção a favor da liberdade", ${ }^{112}$ o que implica na concepção ampla das possibilidades de exercício dos direitos. ${ }^{113} \mathrm{O}$ exercício

107 No direito alemão, o embasamento constitucional de uma suposta "reserva constitucional para a interpretação dos limites imanentes dos direitos fundamentais" - "Verfassungsvorbehalt zur Interpretation immanenter Grundrechtsschranken" (LEPA, Manfred. Grundrechtskonflikte in Deutsches Verwaltungsblatt, 1972. p. 162) - ou "reserva da ordem jurídica" "Rechtsordnungsvorbehalt" (WINKLER, Markus. Kollisionen verfassungsrechtlicher Schutznormen. Berlim: Ducker \& Humblot. 2000. p. 24)-, provém do enunciado do artigo 2, § 1 da LF - exercício do livre desenvolvimento da personalidade contando que não sejam violados os direitos de outrem, a ordem constitucional e a lei moral - recurso argumentativo a que a doutrina denomina "Schrankentrias" ("Tríade de Limites" (Idem, ibidem)) e que inibiria o exercício do direito que fosse "socialmente desvinculado" (NOVAIS, Jorge Reis. As Restrições aos Direitos Fundamentais não expressamente autorizadas pela Constituição. p. 452, nota 788). Segundo a literatura especializada a respeito do tema, teria sido Dürig (1956) o precursor da ideia de estender a aplicação da norma para outros direitos de liberdade (WINKLER, Op. cit., p. 24; LEPA, Manfred. Op. cit., p. 162). Reis Novais salienta que a transmissão da ideia aos direitos de liberdade se dá a partir da "reinterpretação do direito ao desenvolvimento da personalidade como liberdade geral de ação funcionando como matriz de todos os restantes direitos de liberdade" (NOVAIS, Jorge Reis. Op. cit., p. 451).

${ }^{108}$ ALEXY, Robert. Teoria dos Direitos Fundamentais. p. 277; SARLET, Ingo Wolfgang. A Eficácia dos Direitos Fundamentais. p. 389; SILVA, Virgílio Afonso da. Direitos Fundamentais. p. 138.

${ }^{109}$ Cita-se como entendimento contrário: NOVAIS, Jorge Reis. Op. cit., p. 262.

110 Neste sentido: PEREIRA, Jane Reis Gonçalves. Interpretação Constitucional e Direitos Fundamentais: uma contribuição ao estudo das restrições aos direitos fundamentais na perspectiva da teoria dos princípios. Rio de Janeiro: Renovar, 2006. p. 162; SILVA, Virgílio Afonso da. Op. cit., p. 139.

${ }^{111}$ NOVAIS, Jorge Reis. Op. cit., p. 576.

112 MACHADO, Jónatas E.M. A Liberdade de Expressão entre o Naturalismo e a Religião. Coimbra. (policopiado). p. 83; NOVAIS. Jorge Reis. Op. cit., p. 212; MIRANDA, Jorge. Manual de Direito Constitucional. v. IV. 4. ed., Lisboa: Coimbra, 2008. p. 379.

113 Por concepção ampla do âmbito de proteção considera-se o âmbito de proteção com exclusão prévia das condutas que estejam claramente não inseridas na proteção do direito fundamental (NOVAIS, Jorge Reis. Op. cit., p. 427; SARLET, Ingo Wolfgang. Op. cit., p. 390), como é o caso de grande parte das condutas criminosas ou os comportamentos que "apresentem intolerável danosidade social" (NOVAIS, Jorge Reis. Op. cit., pp. 427-428). Para um entendimento "amplíssimo" do âmbito de proteção dos direitos e, portanto, com a consequência de que qualquer delimitação do âmbito de proteção do direito conterá a qualidade de restrição, ver: 
amplo da liberdade gera opções de condutas ilimitadas dos direitos, o que fundamenta a possibilidade de redução desse exercício através de medidas estatais. ${ }^{114}$ Haverá restrição de um direito quando uma ação previamente protegida pelo seu âmbito de proteção vier a ser suprimida pelo fato de entrar em rota de colisão com outro direito ou bem, ${ }^{115}$ cuja solução resultará no direito definitivo. ${ }^{116}$ As atuações restritivas legislativas, para serem legítimas, devem respeitar os pressupostos de legitimidade do Estado de Direito que são estabelecidos na Constituição. Caso contrário, a intervenção será uma violação do direito fundamental e correr-se-á o risco de esvaziamento do conteúdo dos direitos pelo legislador ordinário. ${ }^{117}$ Ao juiz cabe a solução da maioria dos casos de antagonismo de direitos, ou seja, a supressão inteira ou parcial de um ou ambos os direitos resultado do sopesamento em conformidade com as circunstâncias do caso, cuja solução será válida somente para tais fatos em particular.

O todo acima exposto leva a conclusão de que Peter Häberle aceita elementos de ambas as teorias. ${ }^{118}$ É partidário da Teoria Interna dos limites aos direitos fundamentais quando concebe os limites dos direitos "desde dentro" e conforme sua essência. Entretanto, não se opõe à ideia ponderação de bens e direitos como instrumento para a definição dos direitos - ${ }^{119}$ que

ALEXY, Robert. Op. cit., pp. 321 e ss. e SILVA, Virgílio Afonso da. Op. cit., pp. 153-156. Crítica a este modelo, ver: NOVAIS, Jorge Reis. Op. cit., p. 262 e pp. 408 e ss.

${ }_{114}$ BOROWSKI, Martin. La Restricción de los Derechos Fundamentales. p. 34.

115 É como justificativa da intervenção estatal nos direitos fundamentais assegurados sem reserva que Manfred Lepa alerta que "concessão ilimitada da liberdade não quer dizer, em nenhum caso, infinitude" (LEPA, Manfred. Grundrechtskonflikte. p. 165), o que livra a teoria externa de uma proposta individualista e sem preocupações comunitárias (PEREIRA, Jane Reis Gonçalves. Interpretação constitucional e direitos fundamentais. p. 165). Tal assertiva, entretanto, não afasta a existência de direitos que podem ser exercidos sem restrições, pois a necessidade de regulamentação e restrição dos direitos fundamentais decorre somente da "necessidade de compatibilizar diferentes bem jurídicos" (SARLET, Ingo Wolfgang. A Eficácia dos Direitos Fundamentais. p. 389; ALEXY, Robert. Teoria dos Direitos Fundamentais. p. 277).

${ }^{116}$ O termo restrição é empregado genericamente para a "afetação desvantajosa de direitos e liberdades juridicamente protegidos" (CANOTILHO, José Joaquim Gomes. Dogmática de Direitos Fundamentais e Direito Privado. p. 194) o que significa dizer que é toda a ação dos poderes públicos que cause supressão - eliminação, redução ou dificuldade imposta ao acesso ao bem protegido pelo direito (NOVAIS, Jorge Reis. Op. Cit., p. 157) - do âmbito de proteção de um direito fundamental, ou seja, de uma posição - liberdade ou situação - que prima facie estaria contida neste âmbito de proteção do direito (ALEXY, Robert. Op. cit., p. 281), independentemente de ser uma intervenção legítima ou não, ou seja, conforme os parâmetros de legitimidade do Estado de Direito, ou não (CANOTILHO, José Joaquim Gomes. Op. cit., p. 198). A intervenção restritiva ou a restrição em lei são legítimas quando justificáveis constitucionalmente (NOVAIS, Jorge Reis. As Restrições aos Direitos Fundamentais não expressamente autorizadas pela Constituição. p. 207).

${ }^{117}$ ALEXY, Robert. Op. cit., pp. 281 e 292. Tais limites são denominados Limites dos Limites do conceito alemão 'Schranken-Schranke'.

${ }_{118} \mathrm{Em}$ que pese haja o entendimento de que o autor criara uma teoria alternativa em oposição à Teoria Externa das restrições, a que teria denominado "Teoria Institucional dos Direitos Fundamentais" (NOVAIS, Jorge Reis. Op. cit., p. 309-310).

${ }^{119}$ Tais argumentos assemelham-se aos pressupostos teóricos de José Carlos Vieira de Andrade 
são não-restringíveis ${ }^{120}$ mas que entram em colisão - pensamento este refutado pelos autores que se vinculam à Teoria Interna. ${ }^{121}$ A opinião do autor é resultado da consideração da correlação de ambos os bens em conflito, ou seja, é reflexo do entendimento de que os bens e direitos estão inseridos em relações de conformação do âmbito institucional com o âmbito subjetivo. ${ }^{122}$ Assim, a ponderação de bens é a técnica que fará com que os interesses em conflito sejam reconduzidos a uma "coincidência de interesses"123 social e, por isso, individual. A ponderação é responsável por expor os limites, pois imanentes aos direitos, o que resulta na qualificação de toda ação do legislador como declaratória dos limites previamente existentes. $^{124}$

O fato de os direitos fundamentais estarem em convivência com o conjunto da CF e seus demais bens e de a ponderação ser o método pelo

(ANDRADE, José Carlos Vieira de. Os Direitos Fundamentais na Constituição Portuguesa de 1976. Coimbra: Almedina, 1998). A diferença das ideias do jurista alemão e do jurista português é que José Carlos Vieira de Andrade aceita a possibilidade de que os direitos não dispostos com reserva de lei, apesar de não poderem ser restringidos no plano abstrato, podem ser ponderados no caso concreto. Utiliza-se do termo "restrição" para caracterizar a função do legislador atribuída pela reserva - que pressupõe a atividade ponderativa -, mas não admite que tal "restrição" seja empregada sem autorização constitucional - as demais leis são as "leis harmonizadoras" que, "(...) não estando autorizadas a restringir os direitos, visam justamente consagrar, de forma geral e abstrata, soluções para resolução de conflitos" (Idem, p. 321). Assim, a ponderação é utilizada como mecanismo da restrição dos direitos autorizada mediante reserva e na solução do caso concreto - assegurando-se a observância do princípio da concordância prática - possibilitando-se, se necessário, o sacrifício total de um dos direitos opostos (Idem, pp. 325-326).

${ }^{120}$ PEREIRA, Jane Reis Gonçalves. Interpretação Constitucional e Direitos Fundamentais. p. 152. 121 Jane Gonçalves Pereira expõe severa crítica a Peter Häberle a respeito da possibilidade de existência de limites imanentes em concordância com a ideia de colisão de direitos. Entende a autora que a concepção de que os limites dos direitos já estão expostos não coincide com o fato de que os direitos poderiam colidir. A ponderação seria somente aceita para definir o objeto do direito e, para a autora, Peter Häberle, ao aceitar a convivência dos conceitos de conteúdo imanente já definido do direito e de ponderação de bens, acaba por "igualar o objeto da ponderação com o seu resultado" (Idem, p. 155).

${ }^{122}$ Para a compreensão da reserva de lei através da concepção adotada pelo autor há-se que se desvincular da visão de lei como objeto de intervenção e pensar-se o indivíduo de forma vinculada à comunidade e que as exigências dessa comunidade não são intervenções ou restrições aos seus direitos, senão imanentes de sua própria liberdade (HÄBERLE, Peter. La Garantia del Contenido Esencial de los Derechos Fundamentales em la Ley Fundamental de Bonn. pp. 192-193; versão alemã: pp. 206-207). A ideia de limitação dos direitos pela legislação está ligada à ideia de liberdade em contraposição ao direito, que deve ser abandonada (Idem, p. 210; versão alemã: pp. 225-226).

23 SEGRADO, Francisco Fernandéz in HÄBERLE, Peter. La Garantia del Contenido Esencial de los Derechos Fundamentales em la Ley Fundamental de Bonn. p. LVII.

124 PEREIRA, Jane Reis Gonçalves. Op. cit., p. 154. Por isso a conclusão de que as ideias de Peter Häberle acompanham preponderantemente os traços da Teoria Interna. O legislador não tem função criativa de imposição de limites "desde fora", mas os "encontra" no próprio direito. A respeito disso, Jane Pereira também salienta alguns equívocos. Para a autora, a possibilidade de o legislador concretizar os direitos fundamentais confere "peso excessivo ao conteúdo das leis reguladoras, confundindo-as com a própria proteção do direito", leis cujo controle seria menos severo em razão de serem vistas como fruto de atividade interpretativa (Idem, p. 155). 
qual se exponha o conteúdo dos direitos em colisão, já que os limites são imanentes a esses direitos - conforme a tese defendida pelo autor - se dá em razão da dupla dimensão - institucional e subjetiva - dos direitos fundamentais. Não há a possibilidade de restrições desde fora e contrárias aos direitos, pois toda a restrição é uma coordenação ou delimitação do seu conteúdo e, portanto, uma garantia. A autorização para impor limites, concedida ao legislador, é a forma de limitar sua atividade. É assim que Peter Häberle garante que os direitos fundamentais não serão "restringidos" de forma arbitrária e, sim, conformados com a realidade. Qualquer manifestação legislativa contrária a liberdade, de forma a feri-la, não faz parte do seu conteúdo e, por isso, não se trata de restrição (pois só pode restringir-se aquilo que existe), mas lesão ou violação do direito. ${ }^{125}$ Peter Häberle concebe, por tudo isso, apenas dois tipos de reserva: a de conformação do conteúdo e a de delimitação, sendo por esta última que se instrumentaliza o princípio da ponderação de bens. ${ }^{126}$

Faz-se, porém, a ressalva de que Häberle confunde o conceito de limites aos direitos com a ideia de âmbito de proteção dos direitos - ${ }^{127}$ o que é característica do entendimento da Teoria Interna -. Resultado disso, defende que a delimitação e conformação decorrem de uma "reserva geral" que é imanente a todo o direito fundamental. ${ }^{128}$ Embora a Teoria Interna dos limites não compreenda os direitos fundamentais como direitos absolutos, a relativização só seria legítima por força de reserva de lei. Diferentemente, a conclusão que se faz razoável é a de que o autor entende que os direitos possam ser relativizáveis, já que aceita o método ponderativo na definição destes direitos ${ }^{129}$ e deixa clara a compreensão de que a tal artifício

\footnotetext{
${ }^{125}$ NOVAIS, Jorge Reis. As Restrições aos Direitos Fundamentais não expressamente autorizadas pela Constituição. p. 314.

126 Idem, p. 312. Jorge Novais, ao tratar da legislação de reserva, precisa a definição de Peter Häberle: "A legislação feita com base nas reservas não trataria, com efeito, de constituir limites, mas de interpretar ou revelar as fronteiras do conteúdo constitucional dos direitos fundamentais" (Idem, p. 314)

${ }^{27}$ HÄBERLE, Peter. La Garantia del Contenido Esencial de los Derechos Fundamentales em la Ley Fundamental de Bonn. p. 167; versão alemã: p. 179. Defende que os limites são parte do conteúdo dos direitos, razão pela qual o legislador, ao "delimitá-los", determina conteúdos dos mesmos (Idem, ibidem). Tal conteúdo e limites são clarificados por meio da ponderação de bens, esta, obrigação do legislador no sentido de atualizar os bens e direitos (NOVAIS, Jorge Reis. Op. cit., p. 313). Com relação à Teoria Externa, o âmbito de proteção é o direito prima facie constitucionalmente garantido e os limites decorrem da colisão desse direito com outros direitos ou bens, solucionada pelo método da ponderação, que os torna definitivos.

${ }^{128}$ NOVAIS, Jorge Reis. Op. cit., pp. 312-313.

129 MICHAEL, Lothar. El Contenido Esencial como Común Denominador de los Derechos Fundamentales em Europa? in Revista de Derecho Constitucional Europeo, ano 6, Número 11, jan./jun 2009. Disponível em: http://www.ugr.es/ redce/REDCE11/articulos/06LotharMichael.htm. Acesso em: 09.08.2009. p. 8. Apesar de que o autor, ao precisar o uso da ponderação, não aceita que tal metódica atue no sentido de relativizá-los, já que o legislador não teria poderes para agir contrariamente à "lógica da Constituição" (HÄBERLE, Peter. La Garantia del Contenido Esencial de los Derechos Fundamentales em la Ley Fundamental de Bonn. p. 43; versão alemã: p. 42).
} 
metodológico é atribuída a tarefa de combinar a liberdade absoluta individual com as instituições e realidades sociais. ${ }^{130}$

\subsection{O Núcleo Essencial}

Por fim, cumpre comentar a concepção de natureza declaratória da norma do artigo 19.2 da LF - ${ }^{131}$ intangibilidade do núcleo essencial dos direitos fundamentais - feita pelo autor ao final da obra em análise. ${ }^{132}$ Tal preceito teria caráter geral e conteúdo indefinido - designando-a como "cláusula vazia"-, ${ }^{133} \mathrm{e}$, portanto, o denominado "núcleo essencial" dos direitos fundamentais estaria garantido na ordem jurídica pela existência de princípios outros no contexto da Lei Fundamental. ${ }^{134}$ Atenta-se para o fato de que nas ordens constitucionais onde a garantia do núcleo essencial não é positivada, tal limite à atividade legislativa não resta esvaziado em razão da possibilidade de recorrer-se a ela através da combinação de princípios que a ancoram. ${ }^{135}$ Entretanto, o autor não nega a importância do preceito expresso da garantia, já que sua positivação resulta em maior dificuldade para o legislador em transgredi-la. ${ }^{136}$ Por fim, a finalidade da garantia, sendo ela

\footnotetext{
${ }^{130}$ Idem, pp. 41-42; versão alemã: pp. 40-41.

131 Também referido em: HÄBERLE, Peter. Grundrechte und parlamentarische Gesetzgebung im Verfassungsstaat - das Beispiel des deutschen Grundgesetzes. p. 389.

${ }_{132}$ Tal natureza declaratória, segundo Ingo Sarlet, é o que possibilita que a garantia do núcleo essencial seja invocada pelos operadores jurídicos brasileiros, em que pese a norma não ter sido consagrada na Constituição (SARLET, Ingo Wolfgang. A Eficácia dos Direitos Fundamentais. p. 403).

${ }_{133}$ HÄBERLE, Peter. La Garantia del Contenido Esencial de los Derechos Fundamentales em la Ley Fundamental de Bonn. p. 219; versão alemã: p. 235.

${ }^{134}$ Peter Häberle salienta que a cláusula não protege nada além do que já está assegurado pelo próprio conteúdo constitucional do direito e de seus "componentes globais" no âmbito da constituição (HÄBERLE, Peter. Grundrechte und parlamentarische Gesetzgebung im Verfassungsstaat. p. 387 e 389 ).

${ }_{135}$ Conforme já mencionado: SARLET, Ingo Wolfgang. Op. cit., p. 403.

${ }^{136}$ HÄBERLE, Peter. La Garantia del Contenido Esencial de los Derechos Fundamentales em la Ley Fundamental de Bonn. p. 220; versão alemã: p. 235. Cumpre referir que Peter Häberle partilha do entendimento de que mesmo o núcleo essencial dos direitos fundamentais necessita de configuração legislativa (HÄBERLE, Peter. Grundrechte und parlamentarische Gesetzgebung im Verfassungsstaat - das Beispiel des deutschen Grundgesetzes. pp. 374-375). Isso significa que não considera a ideia do núcleo essencial como "barreira impenetrável" de toda e qualquer atividade do legislador (Idem, p. 375), mas que, conforme suas particularidades, requer a conformação legislativa ordinária (Idem, p. 374) - contudo, ainda assim, é protegido contra as limitações/restrições do legislador. Correlacionada a sua concepção de limites imanentes está a ideia de núcleo essencial. O autor concebe uma "integração pragmática de elementos" da Teoria Relativa e da Teoria Absoluta do núcleo essencial dos direitos fundamentais (Idem, p. 387). Isso significa que os direitos são, a um só tempo, absolutos e possíveis de serem submetidos ao método da ponderação de bens: pertence à "essência" dos direitos a possibilidade de serem limitados por outros bens e direitos (de serem ponderados) (Idem, pp. 387-388). Kaufmann, por sua vez, o considera entre os pensadores da "teoria absoluta do núcleo essencial" (KAUFMANN, Arthur. Über den 'Wesensgehalt' der Grund- und Menschenrechte in ARSP, 70, 1984. p. 385) e refere, ao mesmo tempo, que a ideia de que o artigo $19 \mathrm{da} \mathrm{LF}$ teria caráter declaratório é também tributária dos pensadores da teoria relativa do núcleo essencial, que entendem que tal garantia não superaria o que já é resultado da interpretação dos princípios da proibição de excesso, proporcionalidade e ponderação de bens e que tal
} 
expressa ou não, é proteger o conteúdo essencial dos direitos fundamentais de "zonas de perigo", caso haja uma mudança substancial do entendimento concretizado na cultura jurisprudencial e teórica que venha a prejudicar a evolução dogmática dos direitos. ${ }^{137}$

Ao final, cabe uma breve observação. A teoria de autoria do jurista alemão é uma tentativa da superação da imagem negativa da legislação conformadora e de abandono da visão do indivíduo autônomo e sem vinculação à sociedade. Há que considerar seus avanços, sobretudo na exaustiva demonstração da limitação como parte e necessidade da prática do direito para a sua convivência em comunidade. Entretanto, deve-se atentar ao fato de que a negação da atividade "restritiva" do legislador e a ideia de que todo e qualquer limite imposto ao direito faz parte de sua essência podem acarretar problemas. Em especial, porque a negação do uso do termo não exclui a natureza interventiva do ato, o que, sob diferente nomenclatura, legitimaria arbitrariedades sem "controle típico do Estado de Direito". ${ }^{138}$ O que deve ser buscado é a conformação das esferas dos direitos fundamentais - a liberdade do cidadão e as necessidades sociais com a definição das categorias dogmáticas aptas a explicar cientificamente os fenômenos conforme sua natureza e consequências, de forma a facilitar sua aplicação e prezar pela transparência das motivações que possibilite o controle social suficientemente adequado às garantias constitucionais. ${ }^{139}$ Evitar-se-ia, assim, que houvesse diferenciação de espaço de atuação do legislador apenas com base em diferentes determinações terminológicas de adoção de uma ou outra teoria.

natureza declaratória acabaria por relativizá-lo e dar atenção a estes princípios quando o assunto é intervenção nos direitos fundamentais (Idem, p. 387). Apesar disso, Kaufmann refere que a intenção de Häberle e dos defensores da teoria absoluta seria a de "salvar" o artigo 19, 2 da LF, chegando à conclusão de que ele não pretende proteger o direito subjetivo do indivíduo, senão a norma em sentido objetivo, pretenderia a "garantia do instituto jurídico" (Idem, p. 387-389).

${ }^{37}$ HÄBERLE, Peter. Grundrechte und parlamentarische Gesetzgebung im Verfassungsstaat das Beispiel des deutschen Grundgesetzes. p. 389.

138 NOVAIS, Jorge Reis. As Restrições aos Direitos Fundamentais não expressamente autorizadas pela Constituição. p. 317. O que ocorreria seriam legitimações de ações restritivas sem a devida fundamentação racional, manifestadas sob o signo de "limites imanentes" (Idem, p. 320).

${ }^{139}$ SARLET, Ingo Wolfgang. A Eficácia dos Direitos Fundamentais. p. 390. Tais garantias são proporcionadas pela simples mudança do status do individuo após a atuação do Estado, independentemente da nomenclatura do ato. É certo que, muitas vezes, as leis conformadoras acabam por limitar direitos, já que a própria delimitação do âmbito de proteção implica uma colocação de limites (NOVAIS, Jorge Reis. Op. cit., p. 175). O fato de que o resultado de ambas as teorias possa ser semelhante, ou até igual, não quer diz que possam ser equiparadas (SILVA, Virgílio Afonso da. Direitos Fundamentais. p. 157; PEREIRA, Jane Reis Gonçalves. Interpretação Constitucional e Direitos Fundamentais. p. 167). A vantagem da Teoria Externa está na precisão dogmática dos elementos e da motivação aferível intersubjetivamente, mesmo porque, nem todos os problemas de limitação de direitos podem ser solucionados com métodos de interpretação e ignorância dos fatos concretos. 


\section{REFERÊNCIAS BIBLIOGRAFICAS}

ALEXY, Robert. Teoria dos Direitos Fundamentais. Trad. Virgílio Afonso da Silva. São Paulo: Malheiros, 2008.

ANDRADE, José Carlos Vieira de. Os Direitos Fundamentais na Constituição Portuguesa de 1976. Coimbra: Almedina, 1998.

BOROWSKI, Martin. La Restricción de los Derechos Fundamentales. Revista Española de Derecho Constitucional. Madrid: n 59, pp. 29-56, mayo/ago., 2000.

CANOTILHO, José Joaquim Gomes. Dogmática de Direitos Fundamentais e Direito Privado in Estudos sobre Direitos Fundamentais, 2. ed., Coimbra: Coimbra Editora, 2008. pp. 191-215.

HÄBERLE, Peter. Die offene Gesellschaft der Verfassungsinterpreten in JZ, 1975, 10, pp. 297-305.

HÄBERLE, Peter. Die Wesensgehaltgarantie des Art. 19 Abs. 2 Grundgesetz: Zugleich ein Beitrag zum institutionellen Verständnis der Grundrechte und zur Lehre vom Gesetzesvorbehalt. Karlsruhe: Müller, 1962.

HÄBERLE, Peter. Grundrechte und parlamentarische Gesetzgebung im Verfassungsstaat - das Beispiel des deutschen Grundgesetzes in AöR, 114, 3, 1989. pp. 361-390.

HÄBERLE, Peter. Grundrechtsgeltung und Grundrechtsinterpretation im Verfassungsstaat in JZ, 1989, 20, pp. 913-919.

HÄBERLE, Peter. La Garantia del Contenido Esencial de los Derechos Fundamentales em la Ley Fundamental de Bonn: uma contribuición a la concepción institucional de los derechos fundamentales y a la teoria de la reserva de la ley. Trad. Joaquín Brage Camazano. Madrid: Dykinson, 2003.

KAUFMANN, Arthur. Über den 'Wesensgehalt' der Grund- und Menschenrechte in ARSP, 70, 1984. pp. 384-399.

LEPA, Manfred. Grundrechtskonflikte in Deutsches Verwaltungsblatt, 1972. pp. 161-167.

MACHADO, Jónatas E.M. A Liberdade de Expressão entre o Naturalismo e a Religião. Coimbra. (policopiado).

MIRANDA, Jorge. Manual de Direito Constitucional. v. IV. 4. ed., Lisboa: Coimbra, 2008.

MICHAEL, Lothar. El Contenido Esencial como Común Denominador de los Derechos Fundamentales em Europa? in Revista de Derecho Constitucional Europeo, ano 6, Número 11, jan./jun. 2009. Disponível em:

http://www.ugr.es/ redce/REDCE11/articulos/06LotharMichael.htm. Acesso em: 09.08.2009.

NOVAIS, Jorge Reis. As Restrições aos Direitos Fundamentais não expressamente autorizadas pela Constituição. Coimbra: Coimbra Editora, 2003.

PEREIRA, Jane Reis Gonçalves. Interpretação Constitucional e Direitos Fundamentais: uma contribuição ao estudo das restrições aos direitos fundamentais na perspectiva da teoria dos princípios. Rio de Janeiro: Renovar, 2006.

PIEROTH, Bodo; SCHLINCK, Bernhard. Grundrechte, Staatsrecht II. 25. ed., Heidelberg: C.F.Müller, 2009.

SARLET, Ingo Wolfgang. A Eficácia dos Direitos Fundamentais. 10. ed., Porto Alegre: Livraria do Advogado, 2009. 
SEGRADO, Francisco Fernandéz in HÄBERLE, Peter. La Garantia del Contenido Esencial de los Derechos Fundamentales em la Ley Fundamental de Bonn: uma contribuición a la concepción institucional de los derechos fundamentales y a la teoria de la reserva de la ley. Madrid: Dykinson, 2003. Estudo Preliminar, pp. XVII - LXI.

SILVA, Virgílio Afonso da. Direitos Fundamentais: conteúdo essencial, restrições e eficácia. São Paulo: Malheiros, 2009.

WINKLER, Markus. Kollisionen verfassungsrechtlicher Schutznormen. Berlim: Ducker \& Humblot. 2000. 